\title{
Restless legs syndrome in end-stage renal disease patients undergoing hemodialysis
}

\author{
Síndrome de Piernas Inquietas en enfermedad renal crónica terminal en hemodiálisis \\ Sergio Andrés Castillo-Torres', Héctor Raúl Ibarra-Sifuentes², Helda Sánchez-Terán', Concepción Sánchez- \\ Martínez², Beatriz Chávez-Luévanos' Ingrid Estrada-Bellmann
}

\begin{abstract}
Restless legs syndrome (RLS) is a frequent complication of hemodialysis that has been associated with poor quality of life and increased risk for complications. Nevertheless, few studies regarding this entity exist in resource-limited settings. Objectives: To determine the prevalence of RLS among Mexican patients on hemodialysis; and compare these patients with a control group of the same population. Methods: We recruited 105 hemodialysis patients. Restless legs syndrome was diagnosed according to the updated criteria set out by the International RLS Study Group. We selected patients who did not meet the criteria, as controls. Results: We found an RLS prevalence of $18 \%$. The RLS patients had a significantly higher prevalence of iron deficiency anemia and uremic pruritus. None of the patients reported RLS symptoms prior to hemodialysis initiation. Conclusions: Restless legs syndrome is common among Mexican patients on hemodialysis. Larger studies are required to address the impact of RLS in hemodialysis patients.
\end{abstract}

Keywords: Restless legs syndrome; renal dialysis; renal insufficiency.

\section{RESUMEN}

El síndrome de piernas inquietas (SPI) es una complicación de la hemodiálisis que se ha asociado con menor calidad de vida y riesgo aumentado de complicaciones. Sin embargo, existen pocos estudios acerca de esta entidad en escenarios de recursos limitados. Objetivos: Determinar la prevalencia de SPI en pacientes mexicanos en hemodiálisis, y comparar las características con un grupo control de la misma población. Métodos: Reclutamos 105 pacientes en hemodiálisis. El SPI se diagnosticó de acuerdo con los criterios actualizados del grupo de estudio internacional del síndrome de piernas inquietas. Seleccionamos a los pacientes que no cumplieron dichos criterios como controles. Resultados: Encontramos una prevalencia de SPI del 18\%. Los pacientes con SPI tenían una prevalencia más alta de anemia ferropénica, y prurito urémico. Ninguno de los pacientes reportó síntomas de SPI previo a iniciar la hemodiálisis. Conclusiones: El SPI es frecuente en pacientes mexicanos en hemodiálisis; se requieren estudios más grandes para evaluar el impacto del síndrome en ésta población.

Palabras-clave: Síndrome de piernas inquietas; diálisis renal; insuficiencia renal.

Restless legs syndrome (RLS) has frequently been reported as a complication of end-stage renal disease, particularly among patients undergoing hemodialysis. In this population, it has been associated with decrease in quality of life ${ }^{1}$, and increased prevalence of depression and anxiety ${ }^{2}$. Also, an increased risk for cardiovascular events and mortality has been reported in uremic RLS patients ${ }^{3,4}$ in primary RLS, a recent systematic-review and meta-analysis ${ }^{7}$, demonstrated only an increased risk for all-cause mortality and although a hyperadrenergic state has been proposed as an explanation $^{5}$, the precise underlying mechanism is still unknown ${ }^{6}$. In hemodialysis patients, it has been estimated that the prevalence of RLS is higher than that reported for the general population, with available evidence yielding a prevalence ranging from $20 \%$ to $60 \%$, depending on the criteria used for the diagnosis. In Mexico, there is only one study regarding RLS, which reported a prevalence of $15.6 \%$ among 69,830 healthy women ${ }^{8}$, and studies regarding the prevalence of RLS in hemodialysis patients are lacking. Therefore, we designed a study to determine the prevalence of RLS in a Mexican population of patients undergoing hemodialysis, selecting patients who did not meet the criteria for RLS as controls.

\section{METHODS}

\section{Ethics}

Our study received ethical approval number NF15-001 from the Institutional Research Ethics Committee on February $27^{\text {th }}, 2015$. Due to the nature of the study, only informed (nonwritten) assent was required from the subjects.

\footnotetext{
'Servicio de Neurología, Hospital Universitario “Dr. José E. González”, Universidad Autónoma de Nuevo León; Monterrey, NL, México. ${ }^{2}$ Servicio de Nefrología, Hospital Universitario “Dr. José E. González”, Universidad Autónoma de Nuevo León; Monterrey, NL, México. Correspondence: Sergio Andrés Castillo-Torres; Servicio de Neurología, Hospital Universitario “Dr. José E. González”, Universidad Autónoma de Nuevo León; Madero y Gonzalitos S/N, Col. Mitras Centro, Monterrey, NL, México. CP 64460. Telephone: +5218183471059. E-mail: sergio.castillotr@uanl.edu.mx Conflict of interest: There is no conflict of interest to declare.

Received 16 June 2018; Received in final form 25 August 2018; Accepted 25 September 2018.
} 


\section{Study population}

We evaluated 105 patients from the chronic hemodialysis program at our hospital, through a physician-directed interview. The presence of RLS was defined by fulfillment of the essential diagnostic criteria set out by the International RLS Group 9 . Clinical characteristics of patients were obtained by direct interview, and paraclinical parameters were retrieved through medical record review. The control group comprised 86 patients who did not meet the criteria for RLS, recruited while searching for RLS in our hemodialysis program.

\section{Statistical analysis}

We performed statistical analysis of categorical variables using percentage, and for numerical variables, mean and standard deviation, or median and range were used where appropriate. To compare variables between patients and controls, we used the Chi square test for categorical variables; and for numerical variables, the $t$ test and Mann-Whitney U test were used according to the distribution of the variable, as evaluated by the Kolmogorov-Smirnov test. Binary logistic regression was performed to test the association between RLS (present/absent as dependent variable) and the following variables at evaluation as regressors: iron-deficiency anemia (yes/no), length of time undergoing hemodialysis, pruritus (yes/no), and hemoglobin.

\section{RESULTS}

We found 19 patients with RLS (an estimated 18\% prevalence). None of them reported symptoms or diagnosis of RLS prior to the development of end-stage renal disease or initiation of hemodialysis therapy.

Age, sex, and comorbidities were not statistically different between patients with RLS and controls. Among comorbidities, only iron-deficiency anemia was statistically different between RLS patients and controls (63.2\% vs. $37.2 \%$, $\mathrm{p}=0.038$ ). Clinical characteristics are detailed in Table 1.

When compared with controls, RLS had non-significant lower hemoglobin $(7.91 \mathrm{~g} / \mathrm{dL}$ vs. $8.79 \mathrm{~g} / \mathrm{dL}, \mathrm{p}=0.064)$ and hematocrit (24.8\% vs. $27.7 \%, \mathrm{p}=0.055)$; and other red blood cell indices, such as mean corpuscular volume and mean hemoglobin concentration, were not statistically different (Table 2).

The presence of uremic pruritus was significantly higher in patients with RLS than controls ( $42.1 \%$ vs. $20.5 \%, \mathrm{p}=0.039$ ). The course of renal disease, renal replacement therapy, and renal function surrogates (blood urea nitrogen, serum creatinine, and estimated glomerular filtration rate) were not different between groups. Serum electrolyte levels were within normal ranges, and did not differ between groups. Paraclinical characteristics are detailed in Table 2.

Binary logistic regression analysis showed a non-significant trend for iron-deficiency anemia, uremic pruritus and hemoglobin to predict RLS (Table 3), while the length of time undergoing hemodialysis was not significant.

\section{DISCUSSION}

Our study found an 18\% prevalence of RLS in a Mexican hemodialysis population; this prevalence is lower than that reported in previous studies, which ranged from $20 \%$ to $60 \%$, but similar to the only report from our country: $15.6 \%$ in a healthy population of 69,830 women $^{8}$. We must emphasize that this previous Mexican study, although very valuable for being the first to determine the prevalence of RLS, has the limitation that the authors did not use the International RLS Study Group criteria, and patients were asked to answer questions regarding symptoms of RLS, which makes it difficult to ascertain this as the prevalence in a healthy Mexican population. As for the prevalence reported around the world,

Table 1. Clinical characteristics of RLS patients and controls.

\begin{tabular}{|c|c|c|c|}
\hline Variable & RLS & Controls & p-value* \\
\hline Number of participants & 19 & 86 & na \\
\hline Age (years). & $45.5 \pm 17.1$ & $50.2 \pm 16.0$ & $0.253^{a}$ \\
\hline Female sex - no. (\%) & $11(57.9 \%)$ & $47(54.7 \%)$ & $0.797^{b}$ \\
\hline Hypertension - no. (\%) & $18(97.4 \%)$ & $77(89.5 \%)$ & $0.485^{a}$ \\
\hline Diabetes mellitus - no. (\%) & $11(57.9 \%)$ & $48(55.8 \%)$ & $0.869^{a}$ \\
\hline Iron-deficiency anemia - no. (\%) & $12(63.2 \%)$ & $32(37.2 \%)$ & $0.038^{a}$ \\
\hline Peripheral neuropathy - no. (\%) & $2(10.5 \%)$ & $6(7.0 \%)$ & $0.598^{a}$ \\
\hline Cerebrovascular disease - no. (\%) & $2(10.5 \%)$ & $4(4.7 \%)$ & $0.318^{a}$ \\
\hline Duration of end-stage renal disease (years) & $2.5(0.04-9.0)$ & $2.0(0.2-25.0)$ & $0.980^{\circ}$ \\
\hline Duration of undergoing hemodialysis (years) & $2.0(0.04-7.0)$ & $1.65(0.04-13.0)$ & $0.851^{\circ}$ \\
\hline Number of hemodialysis sessions per week - no. (\%) & $2.0(1.0-3.0)$ & $2.0(1.0-4.0)$ & $0.541^{\circ}$ \\
\hline Total number of hemodialysis sessions - no. & $129(5-397)$ & $93(7-483)$ & $0.573^{c}$ \\
\hline Type of access: intravenous catheter. - no. (\%) & $19(100 \%)$ & $76(91.6 \%)$ & $0.167^{a}$ \\
\hline Uremic pruritus - no. (\%) & $8(42.1 \%)$ & $17(20.5 \%)$ & $0.039^{a}$ \\
\hline
\end{tabular}


Table 2. Paraclinical characteristics of RLS patients and controls.

\begin{tabular}{|c|c|c|c|}
\hline Variable & RLS & Controls & $p$-value* \\
\hline Number of participants & 19 & 86 & na \\
\hline Hemoglobin (g/dL) & $7.91 \pm 1.38$ & $8.79 \pm 1.89$ & $0.064^{\mathrm{a}}$ \\
\hline Hematocrit (\%) & $24.8 \pm 4.3$ & $27.7 \pm 5.9$ & $0.055^{a}$ \\
\hline Mean corpuscular volume (fL) & $90.3 \pm 7.4$ & $91.3 \pm 6.0$ & $0.537^{a}$ \\
\hline Mean hemoglobin concentration (pg) & $28.9 \pm 2.8$ & $28.9 \pm 2.1$ & $0.999^{a}$ \\
\hline Platelet count (cell/mm³) & $189,837 \pm 68,866$ & $193,764 \pm 75,257$ & $0.819^{b}$ \\
\hline Mean platelet volume $(\mathrm{fL})$ & $7.12 \pm 1.38$ & $6.80 \pm 1.40$ & $0.341^{b}$ \\
\hline Blood urea nitrogen (mg/dL) & $53.6 \pm 27.3$ & $61.5 \pm 26.8$ & $0.246^{a}$ \\
\hline Serum creatinine (mg/dL) & $9.7 \pm 3.6$ & $9.0 \pm 3.7$ & $0.462^{\mathrm{a}}$ \\
\hline eGFR-MDRD-4 (mL/min/1.73m2) & $7.3 \pm 3.2$ & $8.3 \pm 6.8$ & $0.821^{b}$ \\
\hline Sodium (mmol/L) & $137.1 \pm 2.9$ & $137.3 \pm 4.0$ & $0.848^{\mathrm{a}}$ \\
\hline Potassium (mmol/L) & $5.0 \pm 0.9$ & $5.3 \pm 1.0$ & $0.398^{b}$ \\
\hline Chloride (mmol/L) & $101.9 \pm 4.8$ & $101.7 \pm 4.6$ & $0.886^{a}$ \\
\hline Magnesium (mg/dL) & $2.7 \pm 0.4$ & $2.8 \pm 0.6$ & $0.288^{b}$ \\
\hline Phosphorus (mg/dL) & $5.1 \pm 1.5$ & $5.1 \pm 1.7$ & $0.987^{a}$ \\
\hline Calcium (mg/dL) & $8.2 \pm 0.9$ & $8.4 \pm 1.1$ & $0.699^{b}$ \\
\hline
\end{tabular}

Table 3. Predictors of restless legs syndrome by binary logistic regression analysis.

\begin{tabular}{lccccc}
\hline Variable & Beta & SE & p-value & OR & $95 \% C l$ \\
\hline Iron deficiency anemia & -0.950 & 0.545 & 0.082 & 0.4 & $(0.1-1.1)$ \\
Duration of undergoing hemodialysis (years) & -0.044 & 0.145 & 0.759 & 1.0 & $(0.7-1.3)$ \\
Uremic pruritus & -0.915 & 0.555 & 0.099 & 0.4 & $(0.1-1.2)$ \\
Hemoglobin & -0.304 & 0.183 & 0.096 & 0.7 & $(0.5-1.1)$ \\
\hline
\end{tabular}

Dependent variable: restless legs syndrome (present/absent); Predictors: iron-deficiency anemia (yes/no); duration undergoing hemodialysis; pruritus (yes/no); hemoglobin level.

results have been heterogeneous, due to differences in criteria used for the diagnosis of RLS.

Among differences between RLS patients and controls, we found a significantly higher prevalence of self-reported iron-deficiency anemia. Although iron deficiency has been implicated in the pathogenesis of idiopathic RLS, available evidence (summarized by a recent review ${ }^{10}$ ) suggests that disturbances in the brain's iron metabolism correlate with $\mathrm{RLS}^{11}$, while serum iron parameters do not ${ }^{12}$.

We found a significantly higher prevalence of uremic pruritus in patients with RLS. We did not find any previous studies that associated RLS with uremic pruritus, and the prevalence in our RLS patients was similar to that reported by previous studies in non-RLS patients ${ }^{13}$; both entities have been unsuccessfully proposed as surrogates for inadequate dialysis ${ }^{14}$. Surrogates of renal function, such as serum creatinine, blood urea nitrogen or glomerular filtration rate, did not differ between the RLS patients and controls. While this could suggest that RLS does not develop as a result of inadequate dialysis, many substances that accumulate in endstage renal disease are not routinely measured and the perfect marker for dialysis adequacy has not been found.

Our study is the first to evaluate RLS in a Latino population of patients undergoing hemodialysis using the updated
International RLS Study Group criteria, which have not been used uniformly for diagnosis across available studies.

Our main limitation is the small study sample, which makes it difficult to establish solid differences between patients and controls. We acknowledge that our study lacks invasive or detailed neurophysiological and biochemical measurements that help characterize RLS, such as polysomnographic studies or serum iron status, or dialysis adequacy parameters, such as urea reduction rate. Another important limitation is that we could not measure parathyroid hormone levels. In hemodialysis patients without RLS, evidence linking pruritus and parathyroid hormone has been conflicting $^{15,16}$, while in uremic RLS, elevated parathyroid hormone levels have been associated with poor sleep quality ${ }^{17}$, and in patients with severe hyperparathyroidism, surgical treatment (parathyroidectomy) resulted in an improvement of RLS symptoms ${ }^{18}$. Despite limitations, our findings are useful because they represent the patients encountered in an ordinary practice in a resource-limited setting, such as Mexico. Larger epidemiological studies are required to further assess and define the characteristics of RLS in hemodialysis patients in high risk populations such as Latinos, with a special focus on paraclinical correlates such as parathyroid hormone, in order to elucidate the association with RLS. 
In conclusion, RLS is a common complication in endstage renal disease patients undergoing hemodialysis, and larger studies are required to fully understand the causes and consequences of RLS in hemodialysis patients.

\section{References}

1. Gkizlis V, Giannaki CD, Karatzaferi C, Hadjigeorgiou GM, Mihas C, Koutedakis Y et al. Uremic versus idiopathic restless legs syndrome: impact on aspects related to quality of life. ASAIO J. 2012 NovDec;58(6):607-11. https://doi.org/10.1097/MAT.0b013e31826d6090

2. Dikici S, Bahadir A, Baltaci D, Ankarali H, Eroglu M, Ercan N et al. Association of anxiety, sleepiness, and sexual dysfunction with restless legs syndrome in hemodialysis patients. Hemodial Int. 2014 Oct;18(4):809-18. https://doi.org/10.1111/hdi.12175

3. La Manna G, Pizza F, Persici E, Baraldi O, Comai G, Cappuccilli ML et al. Restless legs syndrome enhances cardiovascular risk and mortality in patients with end-stage kidney disease undergoing long-term haemodialysis treatment. Nephrol Dial Transplant. 2011 Jun;26(6):1976-83. https://doi.org/10.1093/ndt/gfa681

4. Lin CH, Sy HN, Chang HW, Liou HH, Lin CY, Wu VC et al. Restless legs syndrome is associated with cardio/cerebrovascular events and mortality in end-stage renal disease. Eur J Neurol. 2015 Jan;22(1):142-9. https://doi.org/10.1111/ene.12545

5. Innes KE, Selfe TK, Agarwal P. Restless legs syndrome and conditions associated with metabolic dysregulation, sympathoadrenal dysfunction, and cardiovascular disease risk: a systematic review. Sleep Med Rev. 2012 Aug;16(4):309-39. https://doi.org/10.1016/j.smrv.2011.04.001

6. Gholamrezaei A, Amra B, Mortazavi M. Cardiovascular risk and mortality in end-stage renal disease patients with restless legs syndrome; need for further investigation and looking for underlying mechanisms. Sleep Med. 2013 Apr;14(4):385-6. https://doi.org/10.1016/j.sleep.2012.11.015

7. Katsanos AH, Kosmidou M, Konitsiotis S, Tsivgoulis G, Fiolaki A, Kyritsis AP et al. Restless legs syndrome and cerebrovascular/cardiovascular events: systematic review and meta-analysis. Acta Neurol Scand. 2018 Jan;137(1):142-8. https://doi.org/10.1111/ane.12848

8. Lajous M, Kurth T, Catzin-Kuhlmann A, Romieu I, Lopez-Ridaura R. [Prevalence of restless legs syndrome in 69,830 Mexican women]. Rev Invest Clin. 2014 Jul-Aug;66(4):303-6. Spanish.

9. Allen RP, Picchietti DL, Garcia-Borreguero D, Ondo WG, Walters AS, Winkelman JW. Restless legs syndrome/Willis-Ekbom disease diagnostic criteria: updated International Restless Legs Syndrome Study Group (IRLSSG) consensus criteria: history, rationale, description, and significance. Sleep Med. 2014 Aug:15(8):860-73. https://doi.org/10.1016/j.sleep.2014.03.025

10. Garcia-Borreguero D, Williams AM. An update on restless legs syndrome (Willis-Ekbom disease): clinical features, pathogenesis and treatment. Curr Opin Neurol. 2014 Aug;27(4):493-501. https://doi.org/10.1097/WC0.0000000000000117

11. Rizzo G, Manners D, Testa C, Tonon C, Vetrugno R, Marconi S et al. Low brain iron content in idiopathic restless legs syndrome patients detected by phase imaging. Mov Disord. 2013 Nov;28(13):1886-90. https://doi.org/10.1002/mds.25576

12. Oexle K, Schormair B, Ried JS, Czamara D, Heim K, Frauscher B et al. Dilution of candidates: the case of iron-related genes in restless legs syndrome. Eur J Hum Genet. 2013 Apr;21 (4):410-4 https://doi.org/10.1038/ejhg.2012.193

13. Pisoni RL, Wikström B, Elder SJ, Akizawa T, Asano Y, Keen ML et al. Pruritus in haemodialysis patients: international results from the Dialysis Outcomes and Practice Patterns Study (DOPPS). Nephrol Dial Transplant. 2006 Dec;21(12):3495-505. https://doi.org/10.1093/ndt/gfl461

14. Lerma EV. Are restless legs syndrome, pruritus or hiccoughs surrogates for inadequate dialysis? Semin Dial. $2011 \mathrm{Jul}$ Aug;24(4):406-7. https://doi.org/10.1111/j.1525-139X.2011.00888.x

15. Akhyani M, Ganji MR, Samadi N, Khamesan B, Daneshpazhooh M. Pruritus in hemodialysis patients. BMC Dermatol. 2005 Jun;5(1):7. https://doi.org/10.1186/1471-5945-5-7

16. Makhlough A, Emadi N, Sedighi O, Khademloo M, Bicmohamadi AR. Relationship between serum intact parathyroid hormone and pruritus in hemodialysis patients. Iran J Kidney Dis. 2013 Jan;7(1):42-6.

17. Gade K, Blaschke S, Rodenbeck A, Becker A, Anderson-Schmidt H, Cohrs S. Uremic restless legs syndrome (RLS) and sleep quality in patients with end-stage renal disease on hemodialysis: potential role of homocysteine and parathyroid hormone. Kidney Blood Press Res. 2013;37(4-5):458-63. https://doi.org/10.1159/000355727

18. Santos RS, Coelho FM, Silva BC, Graciolli FG, Dominguez WV, Menezes Montenegro FL et al. Parathyroidectomy improves restless leg syndrome in patients on hemodialysis. PLoS One. 2016 May;11(5):e0155835. https://doi.org/10.1371/journal.pone.0155835 